\title{
Analysis of acid-base misconceptions using modified certainty of response index (CRI) and diagnostic interview for different student levels cognitive
}

\author{
Satya Sadhu', Maria Tensiana Tima ${ }^{2}$, Vika Puji Cahyani ${ }^{2}$, Antonia Fransiska \\ Laka $^{2}$, Desfi Annisa ${ }^{2}$, Atina Rizanatul Fahriyah ${ }^{2}$ \\ ${ }^{1,2}$ Chemistry Education Department of Post-Graduate Program, Yogyakarta State University, \\ Colombo Street No 1Yogyakarta 55281, INDONESIA \\ ${ }^{1}$ Email: satyasadhu@,rocketmail.com
}

\begin{abstract}
The authors in this paper draw attention to the importance of an instrument that can analyze student's misconception. This study described the kind of the misconception in acid-base theory, and the percentage students' misconception occur in every subconcept of acid-base theory. The design of this study is a descriptive method, involved 148 of $11^{\text {th }}$ grade science students from Senior High School, which divided into two classes are high cognitive and low cognitive. Further analysis of using Modified Certainty of Response Index (CRI) as a diagnostic instrument is used to explore misconception which in that test included evaluating only content knowledge with considering the reason behind the students' choice of response and their certainty of response in every question. The result of data analysis has shown that misconception occurred in high cognitive class, gained $43,86 \%$ and misconception occurred in low cognitive class, gained $24,63 \%$. Based on the diagnostic interview has shown that misconception occurred in students due to students does not understand the concept well and they related the one concept to the other concepts with partial understanding, the result students make the failed conclusions. The type of misconception occurred is a conceptual misunderstanding. According to the data analysis showed that Modified Certainty of Response Index (CRI) is effective used to analyze students' misconceptions and the diagnostic interview is effective used to know the reasons that caused students which having misconceptions.
\end{abstract}

\section{Introduction}

Science learning process participates in increase education quality. Learning process is learning activity which does by students involved learning sources, facilities, and infrastructures, students and teacher. Piaget's opinion said that learning is a process to establishment knowledge by a student from their experience, which occur continuously [1]. Before going in the formal education every student has their own selves experiences and mindsets, due to establishment different students' prior concept. The expertsconcur that it's not east to move knowledge from the teacher to the student. The student must be active construct their knowledge from new information and experience and new knowledge they have just got. Students hold their knowledge as basic to evaluate new information. If new information is consistent with existing knowledge, new information would be assimilated, but if different at all (contradictory) would be accommodated that knowledge to fit with new information. These ideas, from the students' point of view, 
can be understood in such a way that strongly held by the students. These ideas and conceptions are possibly correct, but most of them are significantly different from accepted scientific viewpoints and tend to be rationalized by students arbitrarily by only considering what they receive from their five senses. Research in student's comprehension of scientific phenomena indicates that student's reason frequent not consistent, different or may not explain the phenomena which directly observed rather than scientific description accepted. It's called misconception.

Chemistry is one of the cornerstones of science, technology and industry. It contributes to our existence, our culture, and our quality of life. It should be taught by comprehensively and coherently. In general, chemistry learning in senior high school more emphasis to the understanding the concept in the level of macroscopic and symbolic, while the understanding of microscopic level infrequent in connected in every concept that teacher taught[9].

Understanding of chemistry concept in chemistry learning is the important point. In fact, the student often has difficulty in understanding various concepts of chemistry. Misconception cause chemistry learning outcomes decrease. Most of senior high school students have difficulities in learning chemistry, therefore mostly of them did not succed in learning chemistry [10].

Lack of understanding of the chemistry concept by student was caused by the nature of chemistry which in abstract and consecutive [4]. The acid and base concept is one of the basic cemistry concept because most of the cemistry reactions are acid-base reactions, but most students hoId misconceptions about acids and bases. Acid-base theory is one of chemistry basic concepts which abstract and involve understanding through microscopic level [8].

Research conducted in many countries showed that misconception occurred in students may be resistant and without cultural boundaries [11]. The wrong concepts or what is named a misconception would cause student also having wrong in the next concept level or can not relate well concept each other. Some of these misconceptions can be removed, but most of them are strongly held by students and usually not affected by regular classroom teaching because it refers to students believe. If the misconceptions are not corrected, new concepts would be difficult to be learned [5]. This situations causes the unbroken chain of misconception because the initial concept that learned by student willserve as the prior concept of the next concept level. The magnitude of impact of misconception in student proves that misconception must be analyzed. The misconception which occurs continuously in student will impact on student learning outcomes that would decrease. Analysis of misconception is intended to know which concepts is the misconception and to know student learning difficulties.

The Certainty of Response Index (CRI) is one way to distinguish between the know the concept, misconceptions, and do not know the concept. CRI is a measure of certainty of the students answers to the questions that given. The certainty of the answer scale portrayed in CRI, CRI value $<2.5$ indicates a lack of confidence of students to answer questions [7]. 
This research instrument combines data collection techniques-choice test on the grounds open (Amir, 1987; Krishnan, 1994) and techniques Certainty of Response Index (CRI) [7]. CRI values (0-5) shows the magnitude of the level of confidence in answering questions. Following criteria set by the CRI value: 0 Total guess the answer; 1 almost guess; 2 not sure; 3 sure; 4 is almost certain; 5 for sure. Basically, The scale gives a level of confidence that the students in answering questions. Number 0 indicates the level of confidence held learners are very low, students answer questions by guessing. This is indicates that students do not know anything about the concepts in question, 5 shows the confidence level of the students in answering questions is very high. They answer questions with knowledge or concepts correct guesses with no element at all. This value is the value given by the students themselves about beliefs when answering each question.

This research was supported with the diagnostic interview to know the consistency in every student who diagnosed have misconception answer on the Modified Certainty of Response Index (CRI). By diagnostic interview, reasonsfrom misconception on students' answer can be analyzed deeply, due to the researcher can get objectiveinformation in student's misconception. On the other hand, interviews can give more detailed information about students' alternative conceptions and their understanding of a particular concept, but a large amount of time is needed to conduct interviews with many students for generalizing their alternative conceptions.

\section{Methodology}

The method of the research is descriptive qualitative. The sample in this study was $11^{\text {th }}$ grade senior high school students in Mataram, taken by purposive random sampling technique by the reason based on the different of cognitive levels, following are low cognitive and high cognitive, selected 4 classes with provision 2 classes has high average as high cognitive class and 2 classes has low average as low cognitive class. Instrument used is modified certainty of response index (CRI) which three level questions (Three-Tier) are objective test in multiple choice question which in students can select four options in every question which be equipped with opened reason and certainty of response index in answer the questions

Data analysis using Microsoft Excel 2007 following are analysis content validity ( Aiken's V test), question item validity (correlation product moment test), reliability using correlation product moment test, item difficulty level, to know the quality of research instrument.

\section{Result and discussion}

Result of analysis of content validity (Aiken's V) instrument based on view and content gained range score $0,851-1$, may be categorized that instrument of modified Certainty of Response Index (CRI) suffice and relevant to measure variable .

Reliability analysis by means product moment test gained $r_{\text {arithmetic }}$ score 0,8217 with significant level, a 5\%, gained $r_{\text {table }}$ score 0,349 . Based on data $r_{\text {arithmetic }}$ score is bigger 
than $r_{\text {table }}$ score, may be concluded that instrument of modified Certainty of Response Index (CRI) is reliable and can be used to further research.

Based on the analysis 35 questions gained items difficulty level of valid items, gained categorized in fool-proof $2,94 \%$, categorized in easy $17,64 \%$, categorized in enough $41,17 \%$, categorized in difficult $26,47 \%$, and categorized in very difficult $11,76 \%$. The result of analysis of 35 questions on distinguishing items of valid items gained, categorized in poor $2,94 \%$, categorized in good enough $8,82 \%$, categorized in good $14,7 \%$, categorized in very good $73,52 \%$. Questions which categorized in poor items may be repaired in sentences or statement and question so may be used in this research.

Test result of using the instrument of Modified Certainty of Response Index (CRI) had been analyzed to know misconception occur in students. On the table below presents the ercentage level of concept comprehension on every tier in instrument of modified Certainty of Response Index (CRI).

Table 1.Percentage Comprehension Levels of Students' Concept on Every Tier

\begin{tabular}{|c|c|c|c|c|c|}
\hline No & Levels & Percentage & $\begin{array}{l}\text { High Cognitive } \\
\text { Class }\end{array}$ & $\begin{array}{l}\text { Low } \\
\text { Class }\end{array}$ & Cognitive \\
\hline \multirow[t]{2}{*}{1} & I Tier & \%Understand & $69,17 \%$ & $66,49 \%$ & \\
\hline & & $\begin{array}{l}\text { \%Did not } \\
\text { understand }\end{array}$ & $30,82 \%$ & $33,51 \%$ & \\
\hline \multirow[t]{3}{*}{2} & II Tier & $\%$ Understand & $41,66 \%$ & $34,65 \%$ & \\
\hline & & $\begin{array}{l}\% \text { Did not } \\
\text { understand }\end{array}$ & $54,41 \%$ & $61,83 \%$ & \\
\hline & & $\%$ Misconception & $3,92 \%$ & $3,50 \%$ & \\
\hline \multirow[t]{3}{*}{3} & III Tier & $\%$ Understand & $41,66 \%$ & $34,65 \%$ & \\
\hline & & $\begin{array}{l}\% \text { Did not } \\
\text { understand }\end{array}$ & $14,12 \%$ & $40,64 \%$ & \\
\hline & & $\%$ Misconception & $43,86 \%$ & $24,63 \%$ & \\
\hline
\end{tabular}

Based on the data analysis of objective test using the instrument of Modified Certainty of Response Index (CRI) showed that there are a lot of students who have misconception either the group who has high cognitive or low cognitive. Percentage of comprehension levels in acid-bases theory can be seen in the table below.

Table 2.Percentage Comprehension Levels of Students' Concept in Acid-Bases Theory

\begin{tabular}{lccc}
\hline \multicolumn{1}{c}{ Indicators } & Percentage & $\begin{array}{c}\text { High Cognitive } \\
\text { Class }\end{array}$ & $\begin{array}{c}\text { Low Cognitive } \\
\text { Class }\end{array}$ \\
\hline Acid-Base of & \%Understand & 46,262 & 30,221 \\
Arrhenius's Theory & \%Misconception & 42,851 & 28,36 \\
& \% Did not & 10,87 & 41,401 \\
\hline
\end{tabular}




\begin{tabular}{lccc}
\hline & understand & & \\
Acid-Base of & \% Understand & 36,314 & 36,904 \\
Bronsted-Lowry's & \%Misconception & 46,461 & 21,154 \\
Theory & \% Did not & 16,215 & 42,024 \\
& understand & & \\
Acid-Base of & \% Understand & 42,409 & 36,83 \\
Lewis's Theory & \%Misconception & 42,283 & 24,391 \\
& \% Did not & 15,296 & 38,51 \\
& understand & & \\
\hline
\end{tabular}

According on the diagnostic interview refers on the table below which in presents the indicator that misconception by students

Table 3.Indicator on acid-base that misconception by the student

\begin{tabular}{|c|c|c|c|c|}
\hline \multirow[b]{2}{*}{ No } & \multirow[b]{2}{*}{ Subconcept } & \multirow[b]{2}{*}{ Concept Indicator } & \multicolumn{2}{|c|}{ Percentage } \\
\hline & & & $\begin{array}{c}\text { High } \\
\text { Cognitive } \\
\text { Class }\end{array}$ & $\begin{array}{c}\text { Low } \\
\text { Cognitive } \\
\text { Class }\end{array}$ \\
\hline \multirow[t]{3}{*}{1} & $\begin{array}{l}\text { Acid-Base of } \\
\text { Arrhenius's }\end{array}$ & $\begin{array}{l}\text { Writing the equation of ionization } \\
\text { reaction }\end{array}$ & $10,44 \%$ & - \\
\hline & Theory & Determining ionization reaction & $80,58 \%$ & - \\
\hline & & $\begin{array}{l}\text { Determining a compound which acts } \\
\text { as an acid-base }\end{array}$ & $24,62 \%$ & $30,43 \%$ \\
\hline \multirow[t]{6}{*}{2} & $\begin{array}{l}\text { Acid-Base of } \\
\text { Bronsted- }\end{array}$ & $\begin{array}{l}\text { Determining a spesi which acts as an } \\
\text { acid-base }\end{array}$ & $42,90 \%$ & $20,28 \%$ \\
\hline & $\begin{array}{l}\text { Lowry's } \\
\text { Theory }\end{array}$ & $\begin{array}{l}\text { Determining an acid-base spesi in } \\
\text { amphiprotic compound }\end{array}$ & $31,34 \%$ & - \\
\hline & & Determining an acid-base conjugation & $42,53 \%$ & $28,98 \%$ \\
\hline & & $\begin{array}{l}\text { Determining characteristics of acid- } \\
\text { base conjugation }\end{array}$ & $44,77 \%$ & - \\
\hline & & Analyzing acid-basespesi & $56,71 \%$ & - \\
\hline & & $\begin{array}{l}\text { Determining a couple of acid-base } \\
\text { conjugation }\end{array}$ & $40,29 \%$ & - \\
\hline \multirow[t]{2}{*}{3} & Acid-Base of & Definition of acid-base & $39,06 \%$ & $28,14 \%$ \\
\hline & Lewis's Theory & $\begin{array}{l}\text { Determining spesi which act as acid } \\
\text { and base }\end{array}$ & $28,35 \%$ & - \\
\hline
\end{tabular}

According to the table 1, can be seen that on one tier which in researcher only know the student who understand the concept and did not understand the concept. It because on one-tier is multiple-choice question test, which multiple-choice has deficiency only can distinguish the student who understands and did not understand the concept. Multiple-choice tests are often more preferable in science classes since they are easy to 
apply and evaluate students' understanding of the related subject, however, multiplechoice tests have some limitations in applying such as determining whether a student gives a correct response to a test consciously or just by chance. The multiple-choice question gives a chance student to guess the right answer about 20\% [16]. The student who answers with the right choice by guessing on the multiple-choice question (onetier) may be categorized in understanding the concept, student who really understand the concept well without guessing may be known by seeing on the two-tier. Calculation on two-tier, percentage student who understands the concept will be decrease and showing the student who actually understand the concept well and student who just lucky chosen the right question. On the two-tier also gained student who was having a misconception. Tsai said opened-reason on two-tier can diagnose the misconception [15]. On two-tier, student gives a reasons or opinions, it may categorizing which in one student who understand the concept, which one student who having misconception or which one student who did not understand the concept. Two-tier is more effective to know misconception and percentage of student understanding of a subject material whether that subject is meaningful or not rather than one tier [16]. On the three-tier may know accurately the student who did not the concept with misconception, because on the three-tier is provided certainty of response index or the level of confidence in answering questions, with the level of confidence student can give scale on their answer, whether they really confidence or not with their answer. Can be concluded that by using the three tier or modified certainty of response index is more effective to know the percentage of student who understand the concept well, did not understand the concept, and misconception. Three-tier tests effectively assess the students understanding rather than conventional multiple choice tests, since three-tier tests also differentiate alternative conceptions from lack of knowledge via analyzing the tiers [3]. According to data from the table 2, may be drawn a graph about the average percentage of students' concept understanding, students' misconception and students did not understanding concept on acid-base in both classes, are in high cognitive class and low cognitive class.
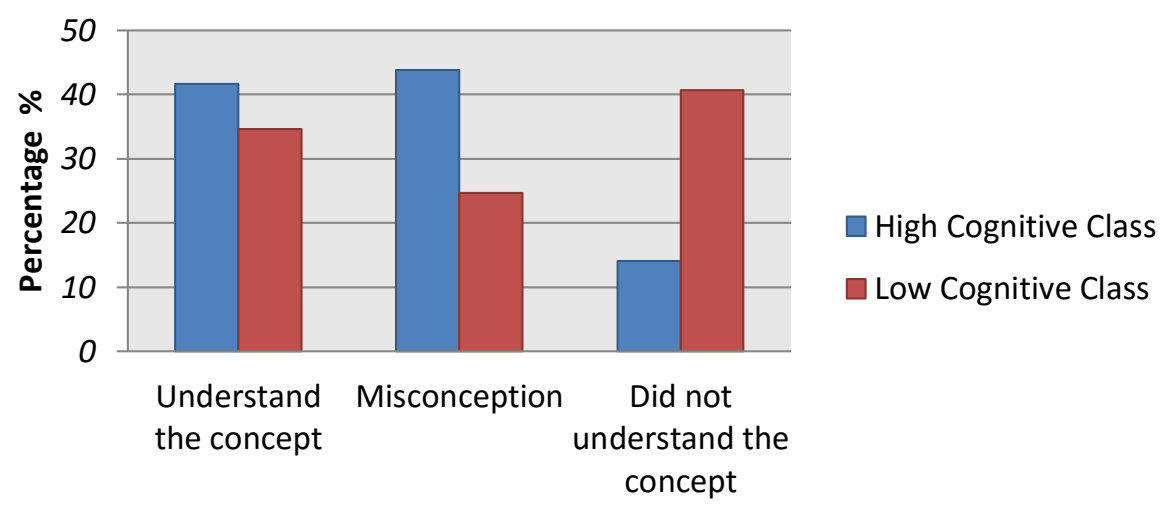

$\square$ Low Cognitive Class

Figure 1.Graph of percentage of the concept comprehension level student in high cognitive and low cognitive class 
The percentage of students' concept understanding in high cognitive class is bigger than percentage of students' concept understanding in low cognitive class. Students in high cognitive class have the high cognitive ability so that student more understanding about the concept which was given by the teacher. The percentage of student misconception in high cognitive class is bigger than the percentage of students' misconception in low cognitive class. Many students in the high cognitive class have high cognitive level which they have higher order thinking skill. Students who have higher order thinking skill tends to have misconception more, rather than students who have lower order thinking skill, because students who have higher order thinking skill have more alternative concepts and tend to interpret a concept in their minds but almost of that concepts different with the true or correct concept [2]. The percentage students who did not understand the concept in high cognitive class are lower than the percentage students who did not understand the concept in low cognitive class. Students in the high cognitive class have cognitive level higher, and completely can understand well the theory, due to the percentage who did not understand the concept is lower than students in the low cognitive class.

Percentage of this comprehension level, supported by the result of Hakim's research, students who have high cognitive level tends occurred misconception rather than students who have a low cognitive level. Percentage of the student who understands the concept in high cognitive class is higher than students in a low cognitive class, and the percentage of student who did not understand the concept in low cognitive class is higher than students in a high cognitive class[6].

Misconception occurred in students in every subconcept of acid-base different either in high cognitive class or low cognitive class. Based on the data in table 4.1 may be showed the percentage misconception in graph occurred in students in every subconcept of acid-base in high cognitive class and low cognitive class.

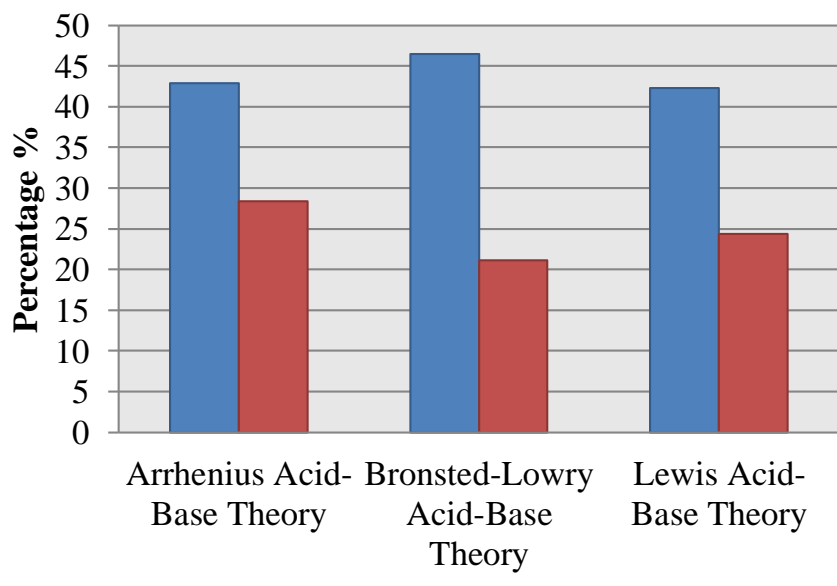

$\square$ High Cognitive Class

- Low Cognitive Class

Figure 2.Graph of Percentage Students' Misconception in High Cognitive Class and Low Cognitive class on Subconcept Acid-Base Theory

Misconception in student caused because student which having the wrong concept when answer the question tends to feel sure or confident about their answer, it is called 
a misconception. The high misconception occurred in the student in high cognitive class and low cognitive class, sourced from students themselves. Conceptual misunderstanding is misunderstanding which flourishes while students are given scientific information which does not give a challenge on paradox [14]. Can be concluded that conceptual misunderstanding is a misapplication of the concept.

Conceptual misunderstanding is kind of a misconception, it is caused by students themselves, who in learning process students try to manage the information to get in their brain, Information accepted consistent with concept structure, this information would directly enhance their knowledge network, this process called assimilation process. Information which did not according with, then they would re-arrangement their cognitive structure till this information may become part of their knowledge network [12]. According to this research, students tend to form a new concept from the other concept, this new concept will facilitate them to understand the existing concept. In fact, this new concept did not according to the true concept, so that students having misconception and student did not confirmation or ask to the teacher about their new concept that they made in the learning process.

Based on the data analysis of misconception occurred in students, can be concluded that students had been understanding the concept is in partial level or incompleted, and tend to memorize. The level of achievement students' concept in identity level. Furthermore some students failed in an interpreting term in acid-base theory. Comins's opinion states that the reasoning students who have incomplete concept caused because information or data which had gained incomplete. As a result, student pulled a wrong conclusion and that could cause misconception appear in the student. Incompleted information or date who gained by students was supported in the learning process in class, teacher presented examples of the concept was not good. According to the observation in class, the teacher did not sort the examples from easy to difficult. The teacher did not choose an example which different from the other example and teacher did not compare and distinguish the example and which not the example [13].

\section{Conclusion}

The kind of misconception is conceptual misunderstanding, it is caused by students themselves. There was misconception occurred in students on acid-base theory. Misconception on acid-base in high cognitive class is $43,865 \%$ and in low cognitive class is $24,635 \%$. Misconception occurred in high cognitive class on acid-base of Arrhenius's Theory gained 42,85\%, acid-base of Bronsted-Lowry's Theory gained $46,46 \%$, and acid-base of Lewis's Theory gained 42,28\%. Misconception occurred in low cognitive class on acid-base of Arrhenius's Theory gained 28,36\%, acid-base of Bronsted-Lowry's Theory gained 21,15\%, and acid-base of Lewis's Theory gained 24,39\%. Misconception in high cognitive class on acid-base of Arrhenius's Theory showed that the higher misconception gained $46,26 \%$ is about student assumed that a compound having $\mathrm{OH}$ is a base. On the Acid-base of Bronsted-Lowry's Theory showed that the higher misconception gained $44,77 \%$ is about student assumed that base conjugation has one atom $\mathrm{H}^{+}$less and has more negative charge than an acid, whereas 
acid conjugation has atom $\mathrm{H}^{+}$more and has more positive charge than a base. On the acid-base of Lewis's Theory showed that the higher misconception gained $56,71 \%$ is about the student assumed that base is a spesi which accepted an electron pair. Misconception in low cognitive class on the acid-base of Arrhenius's Theory showed that the higher misconception gained $24,63 \%$ is about the student assumed that entire of compounds which has structure of $\mathrm{OH}$, if it in ionization reaction would produces a $\mathrm{OH}^{-}$ion (a base). On the acid-base of Bronsted-Lowry's Theory showed the higher misconception gained $36,23 \%$ is about the student assumed that base is a compound which is having less $\mathrm{H}$ element. On the acid-base of Lewis's Theory showed the higher misconception gained $27,53 \%$ is about the student assumed that acid is spesi which give an electron pair.

\section{References}

[1] Aqeel, A, and Ayyal A. 2013. Piaget's Theory of Learning. Interdisciplinary Journal Of Contemporary Research In Business 4(9).

[2] Berg, E V.D. 1991. Miskonsepsi Fisika dan Remediasi. Salatiga: UKSW.

[3] Dindar, A.C, and Omer G. 2011. Development of a three-tier test to assess high school students' understanding of acids and bases. Procedia Social and Behavioral Sciences 15:600-60.

[4] Effendy. 2002. Upaya untuk Mengatasi Kesalahan Konsep dalam Pengajaran Kimia dengan Menggunakan Strategi Konflik Kognitif. Jurnal Media Komunikasi Kimia, 2.

[5] Gonen, S, and Kocakaya, S. 2010, A Physics Lesson Designed According to 7E Model with the Help of Instructional Technology (Lesson Plan), Turkish Online Journal of Distance Education, 11(1): 98-113.

[6] Hakim, A., Liliasari, and Asep K. 2012. Student Concept Understanding of Natural Products Chemistry in Primary and Secondary Metabolites Using the Data Collecting Technique of Modified CR. International Online Journal of Educational Sciences, 4 (3): 544-553.

[7] Hasan, S., Bagayoko, and Kelley E. L. 1999. Misconceptions and the Certainty of Response Index (CRI). Phys. Educ, 34(5).

[8] Hinton, M.E, and Nakhleh M.B. 1999. Students' Microscopic, Macroscopic, and Symbolic Representations of Chemical Reactions. The Chemical Educator, 4(4): 158-167.

[9] Meylindra, I. Suhadi I, and Oktavia S. 2012. Identifikasi Pemahaman Konsep Larutan Asam Basa Melalui Gambaran Mikroskopik Pada Siswa Kelas Xi Ipa Sma Negeri 5 Malang. Jurnal Ilmiah. Universitas Negri Malang.

[10] Nazar, M., Sulastri, Sri W, and Rakhmi F. 2010. Identifikasi Miskonsepsi Siswa SMA Pada Konsep Faktor-faktor yang Mempengaruhi Laju Reaksi. Tesis. Unsyiah Banda Aceh.

[11] Purtadi, S, dan Sari, L.P. 2011. Analisis Miskonsepsi Konsep Laju dan Kesetimbangan Kimia pada Siswa SMA, Makalah, Yogyakarta: Pendidikan Kimia FMIPA, Universitas Negeri Yogyakarta. 
[12] Sanger, M.J, dan Greenbowe, T.J. 1997. Common Student Misconception in Electrochemistry: Galvanic, Electrolytic, and Concentration Cells.Journal of Research in Science Teaching (JRST), 34: 377-398.

[13] Slavin, R.E. 2011. Psikologi Pendidikan Teori dan Praktik. Jakarta: PT. Indeks.

[14] Suparno, P. 2013.Miskonsepsi dan Perubahan Konsep dalam Pendidikan Fisika. Jakarta: Gramedia.

[15] Treagust, D.F, and Reinders D. 2009. Multiple Perspectives of Conceptual Change in Science and the Challenges Ahead. Journal of Science and Mathematics Education in Southeast Asia. 32 (2): 89-104.

[16] Tüysüz, C. 2009. Development of two-tier diagnostic instrument and assess students' understanding in chemistry. Turkey: Department of Primary Education, Mustafa Kemal University. 